into the peritoneal cavity of a guinea-pig Jan. 24th, 1900. The guinea-pig was chloroformed on AIrl 6th. With an emulsion of its spleen two other guinea-pigs were inoculated intra-peritoneally on the same date. One of these was chloroformed on April 28th and cultures were made. Growth was observed first on June 23rd and cultures were made the same day. Growth was abundant and luxuriant.

Culture $U$ (human) was obtained from a child, three years of age, whose death was due to tuberculous meningitis. At the necropsy the lungs and bronchial lymphatic glands were full of miliary tubercles. The anterior mediastinal glands were much enlarged. The spleen was extensively involved, but the liver less so. On the abdominal surface of the diaphragm were a number of flat yellow nodules. 'The mesenteric glands were enlarged and contained old yellow, cheesy nodules. One small tubercle was found in the right suprarenal body. Purulent and cheesy nodules were found in the meninges and in the encephalon. The culture was obtained from the mesenteric glands. The pathologist, Dr. Hand, was uncertain as to the origin of this case. Guineapigs were inoculated intra-neritoneally on June 15th, 1900. One was killed on July 23rd and with its tissues a second was inoculated intra-peritoneally. This was chloroformed on Sept. 12th and cultures were made. On Oct. 11th, no growth having taken place, the blocks of tissue were transferred to fresh serum and stirred. On Dec. 4th growth was first observed and on Dec. 15th sub-cultures were made. Growth has since been rapid and abundant.

Culture $W$ (human). Obtained from a child nine months old, of scrofulous parentage. The cervical glands on both . sides were enlarged. At the necropsy a double bronchopneumonia was found. One small tuberculous nodule was found on the surface of the left lung and several at the apex of the right lung. The bronchial glands were not enlarged. 'The tonsils were normal in size, but the glands on each - side of the pharynx extending in front of and behind the stemo-mastoid muscle were enlarged and tuberculous, and several contained creamy pus. Three mesenteric glands were enlarged and cheesy; an ulcer was found in the jejunum and another at the ileo-cæcal valve. Peyer's patches and the lymphatic glands about the cæcum were enlarged. The spleen and the liver contained tubercles. The mesenteric glands were employed for the isolation of the culture. 'This case was considered by Dr. Hand as being probably of tonsillar or pharyngeal origin. Guinea-pigs were inoculated intra-peritoneally on Oct. 5th, 1900. From one which clied on Jan. 4th, 1901, a second was inoculated intra-peritoneally. This was killed on March 4th and cultures were made. Growth was first observed on April 12th and sub-cultures were made the following day.

Culture BB (human) was obtained from a child 17 months of age. Death was due to tuberculous meningitis. At the mecropsy the lungs were normal, except the posterior and part of the right upper lobe, which was consolidated, red on section, and had excess of connective tissue. 'The bronchial and mediastinal glands were not enlarged. The spleen, the liver, and the kidneys showed pearly tubercles. Two feet from the lower end of the ileum was an ulcer one centimetre by two centimetres, the long diameter of which was transverse to the axis of the gut. Nodules were seen on the peritoneal surface. Four small ulcers, two above and two below, were found in the ileum. The mesenteric glands were enlarged and cheesy and some were purulent. The meninges showed yellow tubercles, most marked along the longitudinal fissure, in the choroid plexus, and over the cerebellum. The mesenteric glands were used in obtaining the culture. This case was considered by Dr. Hand to be the clearest one of primary intestinal tuberculosis ever seen by him. Guineapigs were inoculated intra-peritoneally with an emulsion made from the mesenteric glands on March 9th, 1901. One was chloroformed on April 1 st and cultures were made. Scanty growth on one tube was found on June 8th and subcultures were made.

The results given in Table IV. show for all the bovine cultures a greater virulence than for any of the human cultures. The average life of the guinea-pigs inoculated with human bacilli was more than twice that of those inoculated with bovine. All the rabbits which received human cultures gained in weight and luad finally to be killed, while for the bovine they died, and presented, post mortem, extensive lesions, the lungs and kidneys being the chief seats of the disease in all animals.

(To be continued.)

\section{THE MORTALITY FROM PHTHISIS AND FROM OTHER TUBERCULOUS DISEASES CONSIIDERED IN SOME ASPECTS WHICH MAY BE DEMONSTRATED BY MEANS OF LIFE-TABLES.}

\section{BY T. E. HAYWARD, M.B. LOND., F.R.C.S. ENG.,} MEDICAL OFFICER OF HEALTH OF HAYDOCK, LANCASHIRE.

HERE are gathered together those who are most competent to make clear the conditions under which the battle is raging between tubercle bacilli and the human race, to explain how these, it may be, originally saprophytic fungi have acquired the power of existing in, and preying upon, living animal bodies, and under what circumstances these latter may have their vital resisting power so lowered that they fall a readier prey to their assailants. Here also are those who by position and capacity are best able to plan and to arrange details of sanitary administration which shall give effect to the scientific knowledge laboriously attained by those who have made study of life and disease. Others, too, are here who in various ways have sought to throw light upon the problems involved by means of statistical methods. There is need on a field of battle for some to be told off to count the numbers of the killed and wounded, and without unduly exalting the position of statisticians it may be claimed that those who in the past as well as at present have been working at vital statistics have had some share in awakening the great public interest and attention of which this Congress is the outcome. Exact representations of the numbers of the living who year by year are being cut off by the germs of tuberculosis, together with gradually increasing certainty that phthisis and other tuberculous diseases are to a very large extent preventable, have brought together this great assembly. The simplest mode of statistical representation, of course, is merely to show how many die out of so many living. The next step in advance is by classifying the living population and the deaths into age and sex groups to show the special incidence of the mortality from some particular disease in the respective sexes, and at different periods of life. But instead of asking how many die from a disease out of a thousand or million living we may ask, supposing that this disease could be made extinct, how many more nould be alive at certain ages and how much longer would they live? Now these questions can be answered by means of life-tables.

In some respects this Congress is being held at an unfortunate time. A year hence it might have been possible to utilise the data of the census recently taken and also the tabulated mortality for the decennium just completed, 1891-1900, and so to have obtained results brought down to a very recent period. As it is we have to go back to the numerical facts relating to the decennium 1881-90. What I propose to do is to show how the life-table for England and Wales for 1881-90 would have been affected supposing there had been during the period no deaths from phthisis or from the other tuberculous diseases, and that all the other causes of mortality had retained their proportional intensity. 'This is, of course, a mere hypothesis, but it is a necessary working hypothesis. It is possible that the extinction of one kind of disease germs might leave room for the more active development and diffusion of other kinds, but we can only work on the assumption already made that if some on disease should be eliminated those saved from dring from it will be exposed to the chances of all other diseases in the same proportion as before, and that their average exposure to these chances will be for half the vear This is not the time or place for going into detail as to what a life-table is or how it is constructed. Such knowledge has to be assumed as possessed by those addressed I would, however, desire to emphasise the fact that the work of constructing a complete or "extended" life-table-that is one for every separate year of life-entails an enormou amount of laborious calculation, and that if the object be to have not merely one life-table but a series of life-tables to compare with each other it is practically impossible for one unaided individual to undertake the labour of doing the work by an extended method. The existing duration of life is too

1 A paper communicated to the British Congress on Tuberculosis. Section I., State and Municipal. 
short-one would need to be a Methuselah. Even the late to the Thirty-fifth Annual Report of the Registrar-General, a Dr. William Farr, with his untiring industry and with the advantage of a staff of trained . calculators to help him, employed for the purpose of some comparative life-tables, based on the mortality of England and Wales, for the decennium 1861-70, which were published in the Supplement

TABLE I.-Comparison of Life-table Results as regards Mean Expectation of Life obtained by (a) an Extrnded Method, and $(b)$ the Modified Short Method used in the Construction of the Succeeding Tables.*

1.-Expectation of Life or Mean after Lifetime at cxact

\begin{tabular}{|c|c|c|c|c|c|c|}
\hline \multicolumn{7}{|c|}{ age $x$. } \\
\hline Age. & \multicolumn{3}{|c|}{ Males. } & \multicolumn{3}{|c|}{ Females. } \\
\hline$x$. & $a$. & $b$. & $\begin{array}{l}\text { Differences } \\
\text { of } b \text { from } a \text {. }\end{array}$ & $a$. & $b$. & $\begin{array}{l}\text { Differences } \\
\text { of } b \text { from } a \text {. }\end{array}$ \\
\hline 0 & $43 \cdot 28$ & $43 \cdot 32$ & +0.04 & $46 \cdot 66$ & 46.67 & +0.01 \\
\hline 5 & $52 \cdot 24$ & $52 \cdot 30$ & +0.06 & $54 \cdot 26$ & $54 \cdot 27$ & +0.01 \\
\hline 10 & 48.59 & $48 \cdot 65$ & +0.06 & $50 \cdot 64$ & $50 \cdot 65$ & +0.01 \\
\hline 15 & $44 \cdot 28$ & $44 \cdot 33$ & +0.05 & $46 \cdot 40$ & $46 \cdot 40$ & +0.00 \\
\hline 25 & $36 \cdot 28$ & $36 \cdot 34$ & +0.06 & 38.50 & 38.51 & $\overline{+} 0.01$ \\
\hline .35 & $28 \cdot 91$ & 28.87 & -0.04 & $31 \cdot 16$ & $31 \cdot 03$ & -0.08 \\
\hline 45 & $22 \cdot 06$ & $22 \cdot 04$ & -0.02 & $24 \cdot 05$ & 24.01 & -0.04 \\
\hline .55 & 15.74 & $15 \cdot 71$ & -0.03 & $17 \cdot 23$ & $17 \cdot 12$ & $-0 \cdot 11$ \\
\hline 65 & 10.31 & $10 \cdot 24$ & -0.07 & $11 \cdot 26$ & $11 \cdot 17$ & -0.09 \\
\hline 75 & $6 \cdot 10$ & $6 \cdot c 6$ & -0.04 & $6 \cdot 68$ & $6 \cdot 62$ & -0.06 \\
\hline 85 & 3.29 & 3.32 & +0.03 & 3.71 & $3 \cdot 69$ & -0.02 \\
\hline 95 & $1 \cdot 72$ & $1 \cdot 72$ & \pm 0.00 & $2 \cdot 05$ & $1 \cdot 97$ & +0.08 \\
\hline
\end{tabular}

* The foundation data are those for England and Wales 1881-90, but for $(a)$ the official life-table has been modified by the calculation of a new set of $p \mathrm{x}$ values from $p_{5}$ to $p_{2 \mathrm{x}}$, the other $p_{\mathrm{x}}$ values having been left unaltered.

B.-Shoning hom the Total Expectation of Life at Birth is Distributed nith Respect to the Age-periods indicated.

\begin{tabular}{|c|c|c|c|c|c|c|}
\hline \multirow[b]{2}{*}{ Age-period. } & \multicolumn{3}{|c|}{ Males. } & \multicolumn{3}{|c|}{ Females. } \\
\hline & $a$. & $b$ & $\begin{array}{l}\text { Differences } \\
\text { of } b \text { from } a\end{array}$ & a.. & $b$. & $\begin{array}{l}\text { Differences } \\
\text { of } b \text { from } a \text {. }\end{array}$ \\
\hline $0-5$ & $4 \cdot 02$ & $4 \cdot 02$ & $\pm 0.00_{2}$ & $4 \cdot 16$ & 416 & \pm 0.00 \\
\hline $5-15$ & $7 \cdot 33$ & $7 \cdot 34$ & $\overline{+} 0.01$ & $7 \cdot 63$ & $7 \cdot 65$ & $\overline{+} 0.02$ \\
\hline $15-25$ & $7 \cdot 05$ & $7 \cdot 03$ & -0.02 & $7 \cdot 35$ & $7 \cdot 33$ & -0.02 \\
\hline $25-35$ & $6 \cdot 62$ & $6 \cdot 61$ & -0.01 & 6.90 & 6.89 & -0.01 \\
\hline $25-45$ & $5 \cdot 97$ & $5 \cdot 97$ & \pm 0.00 & $6 \cdot 30$ & $6 \cdot 30$ & $\pm 0 \cdot c 0$ \\
\hline $45-55$ & $5 \cdot 10$ & $5 \cdot 10$ & \pm 0.00 & $5 \cdot 55$ & $5 \cdot 54$ & $\overline{-0.01}$ \\
\hline $55-65$ & $3 \cdot 91$ & $3 \cdot 91$ & \pm 0.00 & $4 \cdot 49$ & $4 \cdot 48$ & -0.01 \\
\hline $65-$ & $3 \cdot 28$ & 3.34 & +0.06 & $4 \cdot 28$ & $4 \cdot 32$ & +0.04 \\
\hline Total ...... & $43 \cdot 28$ & $43 \cdot 32$ & +0.04 & $46 \cdot 66$ & $46 \cdot 67$ & +0.01 \\
\hline
\end{tabular}

C.-Mran Expectation of Life of the Individuals at all Ages from $x$ to $x+n$ comprised within the Age-groups $x$ to $x+n$ indicater.

\begin{tabular}{|c|c|c|c|c|c|c|}
\hline \multirow{2}{*}{$\begin{array}{l}\text { Age } \\
\text { groups } \\
\text { to } x+n .\end{array}$} & \multicolumn{3}{|c|}{ Males. } & \multicolumn{3}{|c|}{ Females. } \\
\hline & $a$. & $b$ & $\begin{array}{l}\text { Differences } \\
\text { of } b \text { from } a .\end{array}$ & $a$. & $b$. & $\begin{array}{l}\text { Differences } \\
\text { of } b \text { from } a \text {. }\end{array}$ \\
\hline $0-5$ & $51 \cdot 76$ & $51 \cdot 76$ & +0.00 & $54 \cdot 07$ & $54 \cdot 07$ & $+0 . \mathrm{CO}$ \\
\hline $5-10$ & 50.57 & $50 \cdot 58$ & +0.01 & $52 \cdot 60$ & $52 \cdot 56$ & -0.04 \\
\hline $10-15$ & $46 \cdot 43$ & $46 \cdot 49$ & +0.06 & $48 \cdot 52$ & 48.53 & +0.01 \\
\hline $15-25$ & $40 \cdot 27$ & $40 \cdot 33$ & +0.06 & $42 \cdot 44$ & $42 \cdot 46$ & +0.02 \\
\hline $25-35$ & $32 \cdot 60$ & $32 \cdot 61$ & +0.01 & 34.83 & $34 \cdot 82$ & -0.01 \\
\hline $35-45$ & $25 \cdot 51$ & $25 \cdot 48$ & -0.03 & $27 \cdot 66$ & $27 \cdot 65$ & -0.01 \\
\hline $45-55$ & $18 \cdot 95$ & $18 \cdot 93$ & -0.02 & $20 \cdot 67$ & $20 \cdot 63$ & -0.04 \\
\hline $55-65$ & 13.09 & 13.06 & -0.03 & $14 \cdot 30$ & $14 \cdot 24$ & -0.06 \\
\hline $65-75$ & $8 \cdot 35$ & $8 \cdot 34$ & -0.01 & $9 \cdot 08$ & $9 \cdot 06$ & -0.02 \\
\hline $75-85$ & $4 \cdot 94$ & $4 \cdot 94$ & +0.00 & $5 \cdot 41$ & $5 \cdot 41$ & +0.00 \\
\hline $85-95$ & $2 \cdot 80$ & $2 \cdot 78$ & -0.02 & $3 \cdot 16$ & $3 \cdot 11$ & -0.05 \\
\hline $95-$ & 1.57 & $I \cdot 62$ & +0.05 & $1: 86$ & 1.87 & +0.01 \\
\hline
\end{tabular}
short or abbreviated method, details of which are given in the same supplement. Another point which I would wish to lay special stress upon is that, in order to be fairly comparable with each other the life-tables must be calculated by the same methorl. If the occasion permitted I could give ample proof of this by comparative figures, worked out from the same data by different methods. Now, in some experimental work on life-table calculation I happened about three years ago to hit upon some very simple modifications of Dr. Farr's original method of constructing a short life-table, which gave results approximately to those of an extended life-table with remarkable closeness. $^{2}$ By this method the expectation of life can be

TABLE II.-Life-table for England and Wales for the Decennium. 1851-60 based on the true Mean Numbers Living deduced from the Census Returns of 1851 and 1861 and on the Deaths from all Causes during the Ten Iears $1851-60$.

\begin{tabular}{|c|c|c|c|c|c|c|}
\hline \multirow[t]{3}{*}{ Age. } & \multirow{2}{*}{\multicolumn{2}{|c|}{$\begin{array}{c}\begin{array}{c}\text { Chance of living } \\
\text { one vear in the } \\
\text { interval from } \\
\text { age } x .\end{array} \\
\underbrace{}_{p x} .\end{array}$}} & \multirow{2}{*}{\multicolumn{2}{|c|}{$\overbrace{l x .}^{\begin{array}{c}\text { Number of sur- } \\
\text { virors at age } x \\
\text { out of a } \\
\text { million born. }\end{array}}$}} & \multirow{2}{*}{\multicolumn{2}{|c|}{$\begin{array}{l}\begin{array}{c}\text { Expectation of life, } \\
\text { or mean after-life- } \\
\text { time at age } x, \text { ex- } \\
\text { pressed in years. }\end{array} \\
\underbrace{}_{E x .}\end{array}$}} \\
\hline & & & & & & \\
\hline & Males. & Females. & Males. & Females. & Males. & Females \\
\hline 0 & 0.83236 & 0.86227 & $1,000,000$ & $1,000,000$ & $42 \cdot C 6$ & $42 \cdot 15$ \\
\hline 1 & 0.93537 & 0.93820 & 832.364 & 862,266 & $47 \cdot 06$ & $47 \cdot 82$ \\
\hline 2 & 0.96502 & 0.96527 & 778,567 & 808,980 & $49 \cdot 28$ & $49 \cdot 93$ \\
\hline 3 & 0.97607 & 0.97596 & 751,336 & 780,882 & $50 \cdot 04$ & $53 \cdot 71$ \\
\hline 4 & 0.98225 & 0.98222 & 743,353 & 762,110 & $50 \cdot 26$ & $50 \cdot 95$ \\
\hline 5 & 0.99149 & 0.99158 & 720,337 & 748,559 & $50 \cdot 16$ & $50 \cdot 8$ \\
\hline 10 & 0.99512 & 99494 & 690,211 & 717,585 & $47 \cdot 24$ & 47.95 \\
\hline 15 & 0.99230 & 0.99205 & 673,528 & 699,616 & $43 \cdot 35$ & $44 \cdot 12$ \\
\hline 25 & 0.99046 & 0.99010 & 623,450 & 645,945 & $36 \cdot 43$ & $37 \cdot 37$ \\
\hline 35 & 0.98754 & 0.98786 & 566,449 & 584,755 & $89 \cdot 51$ & $30 \cdot 77$ \\
\hline 45 & 0.98212 & 0.98483 & 499,705 & $517,5 \varepsilon 9$ & $22: 80$ & $24 \cdot 12$ \\
\hline 55 & 0.96944 & 0.97322 & 417,238 & 444,190 & $16 \cdot 34$ & $17 \cdot 30$ \\
\hline 65 & 0.93646 & 0.94276 & 305,883 & 338,585 & $10 \cdot 53$ & $11 \cdot 19$ \\
\hline 75 & 0.86297 & 0.87380 & 158,655 & 187,797 & 6.03 & $6 \cdot 45$ \\
\hline 85 & $0 \cdot 73198$ & & 36,343 & 48,731 & 3.29 & $3 \cdot 48$ \\
\hline 95 & 0.55138 & 0.56783 & 1,605 & 2,637 & $1 \cdot 73$ & $1 \cdot 81$ \\
\hline
\end{tabular}

TABLE III.--Shoring the Differences from Table II. produced by Excluding Phthrsis as a Cause of Mortality in England and Wales during 1851-60.

\begin{tabular}{|c|c|c|c|c|c|c|}
\hline \multirow{3}{*}{$\begin{array}{c}\text { Age. } \\
\qquad x\end{array}$} & \multirow{2}{*}{\multicolumn{2}{|c|}{$\begin{array}{c}\text { Chance of living } \\
\text { one year in the } \\
\text { interval from } \\
\text { age } x .\end{array}$}} & \multirow{2}{*}{\multicolumn{2}{|c|}{ 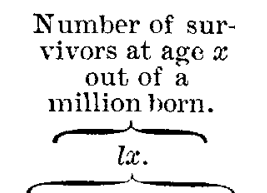 }} & \multirow{2}{*}{\multicolumn{2}{|c|}{$\begin{array}{c}\text { Expectation of life } \\
\text { or mean after-life- } \\
\text { time at age } x, \text { ex- } \\
\text { pressed in years. }\end{array}$}} \\
\hline & & & & & & \\
\hline & Males. & Females. & Males. & Females. & Males. & Females. \\
\hline 0 & +0.00206 & +0.00188 & - & - & $+3 \cdot 37$ & $+4 \cdot 01$ \\
\hline 1 & +0.00171 & $+0 \cdot c 0166$ & $+2, c 53 !$ & $+1,882$ & $+3 \cdot 92$ & +4.54 \\
\hline 2 & +0.00097 & $+0^{\circ} \mathrm{c} 01 \mathrm{co}$ & $+3,352$ & $+3,201$ & $+4 \cdot c 9$ & $+4 \cdot 75$ \\
\hline 3 & +0.00059 & +0.00063 & $+3,987$ & +3 & $+4 \cdot 19$ & $+4 \cdot 86$ \\
\hline 4 & +0.06053 & +0.00058 & $+4,336$ & $+4,3$ & $+4 \cdot 25$ & $+4 \cdot 94$ \\
\hline 5 & +0.00052 & $+0^{\circ} 0$ & $+4,689$ & $+4,6$ & $+4 \cdot 30$ & $+5 \cdot 00$ \\
\hline 10 & +0.00076 & $+0 . \mathrm{C}$ & $+6,270$ & $+6,71$ & $+4 \cdot 35$ & +5.04 \\
\hline 15 & +0.00317 & $+0 \cdot$ & $+8,712$ & $+11,132$ & $+4 \cdot 26$ & $+4 \cdot 83$ \\
\hline 25 & +0.00400 & +0.0 & $+28,508$ & +36 & $+3 \cdot 16$ & $+3 \cdot 41$ \\
\hline 35 & +0.00396 & $+0 \cdot \mathrm{C}$ & $+50,256$ & +61 & $+2 \cdot 06$ & $+1 \cdot 99$ \\
\hline 45 & +0.00376 & +0.00308 & $+66,567$ & $+79,2$ & $+1 \cdot 14$ & +0.97 \\
\hline 55 & +0.00321 & +0.00230 & $+73,966$ & $+84,209$ & +0.51 & +0.40 \\
\hline 65 & +0.00217 & +0.00152 & $+66,361$ & $+73,829$ & $+0 \cdot 16$ & $+0 \cdot 12$ \\
\hline 75 & +0.00079 & +0.00062 & $+38,931$ & $+44,631$ & +0.04 & +0.02 \\
\hline 85 & +0.00034 & +0.00031 & $+9,433$ & $+12,010$ & +0.01 & +0.01 \\
\hline 95 & - & - & $+\quad 421$ & +663 & - & - \\
\hline
\end{tabular}

2 For a description of the methods and for comparative figures, in illustration and proof, reference may be made to Public Health, vol. xi., 
calculated at quinquennial age-intervals, with results differing by only from 0.01 to $0 \cdot 10$ of a year, from the result obtainable by what I believe to have been the most accurate extended method-that is practically only varying to the extent of from a few days to a few weeks. Indeed, the results approximate much more closely than do those obtained by extended life-tables worked out, by different methods. It has been, perhaps, necessary to say so much in support of the claim to be made that the method which has been adopted in working out the appended tables is a sufficiently accurate instrument for statistical research. Table I., with its three divisions-A, B, and $\mathrm{C}-$ is intended to illustrate and support this preliminary claim. What has been hitherto published of the references already given has relation only to the results

TABLE IV.-Life-table for England and Wales for the Decennium 1881-90, based on the Data of the Official Life-table, but Caloulated by the same Modified Short Method as that Used for the Other Tables in the Series.

\begin{tabular}{|c|c|c|c|c|c|c|}
\hline \multirow{3}{*}{$\begin{array}{c}\text { Age. } \\
x .\end{array}$} & \multirow{2}{*}{\multicolumn{2}{|c|}{$\begin{array}{l}\begin{array}{c}\text { Chance of living } \\
\text { one year in the } \\
\text { interval from } \\
\text { age } x .\end{array} \\
\underbrace{}_{p x} x .\end{array}$}} & \multirow{2}{*}{\multicolumn{2}{|c|}{$\overbrace{l x .}^{\begin{array}{c}\text { Number of sur- } \\
\text { vivors at age } x \\
\text { out of a million } \\
\text { born. }\end{array}}$}} & \multirow{2}{*}{\multicolumn{2}{|c|}{$\begin{array}{l}\begin{array}{c}\text { Expectation of life } \\
\text { or mean after-life- } \\
\text { time at age } x, \text { ex- } \\
\text { pressed in years. }\end{array} \\
\underbrace{}_{E x .}\end{array}$}} \\
\hline & & & & & & \\
\hline & Males. & Females. & Males. & Females. & Males. & Females. \\
\hline 0 & 0.83896 & 0.86887 & $1,000,000$ & $1,000,000$ & $43 \cdot 32$ & $46 \cdot 67$ \\
\hline 1 & 0.94870 & 0.94729 & 838,964 & 868,874 & $50 \cdot 56$ & $52 \cdot 66$ \\
\hline 2 & 0.97617 & 0.97700 & 790,891 & 823,072 & $52 \cdot 61$ & $54 \cdot 56$ \\
\hline 3 & 0.98461 & 0.98487 & 772,046 & 804,142 & $52 \cdot 88$ & $54 \cdot 83$ \\
\hline 4 & 0.98859 & 0.98898 & 760,167 & 791,973 & $52 \cdot 70$ & $54 \cdot 66$ \\
\hline 5 & 0.99467 & 0.99475 & 751,494 & 783,244 & $52 \cdot 30$ & $54 \cdot 27$ \\
\hline 10 & 0.99705 & 0.99689 & 731,669 & 762,910 & $48 \cdot 65$ & $50 \cdot 65$ \\
\hline 15 & 0.99504 & 0.99504 & 720,942 & 751,135 & $44 \cdot 33$ & $46 \cdot 40$ \\
\hline 25 & 0.99226 & 0.99265 & 685,947 & 714.724 & $36 \cdot 34$ & $38 \cdot 51$ \\
\hline 35 & 0.98768 & 0.98946 & 634,654 & 663,880 & $28 \cdot 87$ & $31 \cdot 08$ \\
\hline 45 & $0 \cdot 98080$ & 0.98500 & 560,634 & 597,164 & $22 \cdot 04$ & $24 \cdot 01$ \\
\hline 55 & 0.96587 & 0.97192 & 461,836 & 513,384 & $15 \cdot 71$ & $17 \cdot 12$ \\
\hline 65 & 0.93190 & 0.94132 & 326,327 & 386,134 & $10 \cdot 24$ & $11 \cdot 17$ \\
\hline 75 & 0.86328 & 0.87726 & 161,189 & 210,907 & 6.06 & $6 \cdot 62$ \\
\hline 85 & 0.73462 & 0.76126 & 37,056 & 56,934 & $3 \cdot 32$ & $3 \cdot 69$ \\
\hline 95 & 0.54941 & 0.59522 & 1,696 & 3,721 & 1.72 & $1 \cdot 97$ \\
\hline
\end{tabular}

TABLE V.-Shoming the Difference from Table IV. produced by Excluding Phthisis as a Cause of Mortality in England and Wales during the 10 Years 1881-90.

\begin{tabular}{|c|c|c|c|c|c|c|}
\hline \multirow{3}{*}{$\begin{array}{l}\text { Age. } \\
x . \\
x\end{array}$} & \multirow{2}{*}{\multicolumn{2}{|c|}{$\begin{array}{c}\begin{array}{c}\text { Chance of living } \\
\text { one year in the } \\
\text { interval from } \\
\text { age } x .\end{array} \\
\underbrace{}_{p x .}\end{array}$}} & \multirow{2}{*}{\multicolumn{2}{|c|}{$\overbrace{l x .}^{\begin{array}{c}\text { Number of sur- } \\
\text { vivors at age } x \\
\text { out of a } \\
\text { million born. }\end{array}}$}} & \multirow{2}{*}{\multicolumn{2}{|c|}{$\begin{array}{l}\begin{array}{c}\text { Expectation of life, } \\
\text { or mean after-life- } \\
\text { time at age } x, \text { ex- } \\
\text { pressed in years. }\end{array} \underbrace{}_{E x .}\end{array}$}} \\
\hline & & & & & & \\
\hline & Males. & Females. & Males. & Females. & Males. & Females. \\
\hline 0 & +0.00088 & +0.00076 & - & - & +2.58 & $+2 \cdot 57$ \\
\hline 1 & +0.00074 & +0.00072 & +874 & +758 & $+3 \cdot 02$ & $+2 \cdot 90$ \\
\hline 2 & +0.00039 & +0.00037 & $+1,442$ & $+1,345$ & $+3 \cdot 15$ & +3.02 \\
\hline 3 & +0.00030 & +0.00027 & $+1,710$ & +1.619 & $+3 \cdot 21$ & $+3 \cdot 07$ \\
\hline 4 & +0.00023 & +0.00026 & $+1,883$ & +1.816 & $+3 \cdot 24$ & $+3 \cdot 11$ \\
\hline 5 & +0.00025 & +0.00033 & $+2,039$ & +2.007 & $+3 \cdot 27$ & $+2 \cdot 12$ \\
\hline 10 & +0.00034 & +0.00070 & $+2,912$ & $+3,2 C 9$ & $+3 \cdot 29$ & $+3 \cdot 11$ \\
\hline 15 & +0.00177 & +0.00205 & $+4,113$ & $+5,810$ & $+3 \cdot 26$ & +2.98 \\
\hline 25 & +0.00301 & +0.00278 & $+16,284$ & $+20,510$ & $+2 \cdot 58$ & $+2 \cdot 19$ \\
\hline 35 & +0.00352 & +0.00271 & $+35,065$ & $+38,420$ & $+1 \cdot 75$ & $+1 \cdot 29$ \\
\hline 45 & +0.00342 & +0.00202 & $+52,430$ & $+52,048$ & +0.96 & +0.61 \\
\hline 55 & +0.00278 & +0.00146 & $+61,072$ & $+56,299$ & +0.41 & +0.25 \\
\hline 65 & +0.00164 & +0.00089 & $+53,939$ & $+48,815$ & +0.12 & +0.08 \\
\hline 75 & +0.00059 & +0.00036 & $+29,988$ & $+28,936$ & +0.02 & +0.01 \\
\hline 85 & +0.00018 & +0.00013 & $+7,195$ & $+8,074$ & +0.01 & \pm 0.00 \\
\hline 95 & - & - & $+\quad 334$ & $+\quad 535$ & - & - \\
\hline
\end{tabular}

vol. lxii., parts 3 and 4, Scptember and December, 1899. My friend Dr. A. Newsholme has also done me the honour to insert a cescription of Statistics" (see Chapter xxiii., page 279). in division $A$; certain other simple devices, by which the short method may be made to yield the results set down in divisions $\mathrm{B}$ and $\mathrm{C}$, have occurred to me while engaged in preparing this communication. At some time ere long I hope to publish the details of the arithmetical methods. employed. The other tables will to a large extent be left to speak for themselves. The data upon which the calculations have been made are to be found in the Annual Report and Decennial Supplements of the Registrar-General. As it seemed desirable to make at least one comparison with an earlier period.I have prepared Tables II. and III., which are intended to demonstrate the effect of excluding phthisis as a canse of mortality in England and Wales during the 10 years 1851-60. Table II. is one of a series as yet unpublished. Table III. has the same relation to Table II. as Table V. has to Table IV. The comparison serves to further illustrate what already was evident by the ordinary death-rate-that the mortality from phthisis has much diminished. Some of the decrease may be, of course, only apparent-we have to consider the less accuracy of diagnosis at the early period and also possible cyclical variations in the intensity of the disease; but the opinion is at least very generally held that a large proportion of the lessened mortality is real and is the result of improved sanitation and bettered conditions of life. Attention may be specially directed to the altered sex incidence of this disease, the mortality being greater among females in 1851-60, from age two to age 35, whereas, except at ages four, five, 10, and 15, during 1881-90, it was greater among males. The remaining 'Tables relate to the 10 years 1881-90. Tables IV., V., and VI. afford answers to these three questions-supposing that (1) phthisis

TABLE VI.-Showing the Difference from Table IV: produced by Excluding Phthisis and all other Tuberoulous. Diseases as Causes of Mortality in England and Wales during the 10 Years 1881-90.

\begin{tabular}{|c|c|c|c|c|c|c|}
\hline \multirow{3}{*}{$\begin{array}{l}\text { Age. } \\
x .\end{array}$} & \multirow{2}{*}{\multicolumn{2}{|c|}{$\begin{array}{c}\begin{array}{c}\text { Chance of living } \\
\text { one year in the } \\
\text { interval from } \\
\text { age } x .\end{array} \\
\text {. }\end{array}$}} & \multirow{2}{*}{\multicolumn{2}{|c|}{$\begin{array}{c}\begin{array}{c}\text { Number of sur- } \\
\text { vivors at age } x \\
\text { out of } a \\
\text { million born. }\end{array} \\
\overbrace{l x .}\end{array}$}} & \multirow{2}{*}{\multicolumn{2}{|c|}{$\begin{array}{l}\begin{array}{c}\text { Expectation of life } \\
\text { or mean after-life- } \\
\text { time at age } x, \text { ex- } \\
\text { pressed in years. }\end{array} \\
\overbrace{E x .}\end{array}$}} \\
\hline & & & & & & \\
\hline & Males. & Females. & Males. & Females. & Males. & Females. \\
\hline 0 & $+0 \cdot 01007$ & +0.00785 & - & - & +388 & $+3 \cdot 72$ \\
\hline 1 & +0.00639 & +0.00524 & $+10,062$ & $+7,844$ & +3.94 & $+3 \cdot 76$ \\
\hline 2 & +0.00274 & +0.00228 & $+14,910$ & $+12,025$ & +3.79 & $+3 \cdot 65$ \\
\hline 3 & +0.00156 & +0.00143 & $+16,762$ & $+13,654$ & $+3 \cdot 72$ & $+3 \cdot 60$ \\
\hline 4 & +0.00123 & +0.00113 & $+17,734$ & $+14,621$ & $+3 \cdot 69$ & $+3 \cdot 58$ \\
\hline 5 & +0.00081 & +0.00087 & $+18,486$ & $+15,375$ & $+3 \cdot 66$ & $+3 \cdot 54$ \\
\hline 10 & +0.00063 & +0.00103 & $+21,062$ & $+18,375$ & +3.54 & $+3 \cdot 39$ \\
\hline 15 & +0.00196 & +0.00226 & $+23,092$ & $+22,064$ & $+3 \cdot 44$ & $+3 \cdot 18$ \\
\hline 25 & +0.00314 & +0.00291 & $+36,087$ & $+37,855$ & $+2 \cdot 73$ & +2.29 \\
\hline 35 & +0.00363 & +0.00282 & +-54.825 & $+55,929$ & +1.81 & $+1 \cdot 35$ \\
\hline 45 & +0.00352 & +0.00210 & $+71,201$ & $+68,943$ & +0.99 & +0.64 \\
\hline 55 & +0.00288 & +0.00154 & $+77,658$ & +71.616 & +0.42 & +0.26 \\
\hline 65 & +0.00173 & +0.00096 & $+66,416$ & $+60,874$ & $+0 \cdot 12$ & $+0 \cdot c a$ \\
\hline 75 & +0.00063 & +0.00040 & $+26,432$ & $+35,769$ & +0.02 & +0.01 \\
\hline 85 & +0.00019 & +0.00015 & $+8,706$ & $+9,962$ & +0.01 & \pm 0.00 \\
\hline 95 & - & - & $+\quad 404$ & $+\quad 660$ & - & - \\
\hline
\end{tabular}

and (2) the whole group of tuberculous dieases had had no existence as canses of mortality in England and Wales. during 1881-90, at each of the ages indicated respectively(a) how much greater would have been the chance of surviving to the end of one year? $(b)$ how many more would be living at each age? and (c) how much greater would be the mean expectation of life, or, in other words, the mean after-lifetime of each age? With regard to the $l x$ columnsthat is, the successive numbers of survivors at age $x$-it must be borne in mind that the results of the short method are more and more in excess of those obtained by the extended method from about 25 years of age onwards. However, as the three Tables IV., V., and VI. are worked out by the same method the results are fairly comparable in their proportions to each other. The $E x$ columns are of the greatest importance, and these, as has been shown, are practically identical with those to be obtained by the extended method. The fact which stands out from all 
others is that if there had been no phthisis the average length of life for each individual born nould have been ancrensed by two and a half years. Another prominent fact is that those who have survived to the age of 15 years would have their average expectation of life increased by about three and a quarter years. Now these hypothetical results are greater than those which would be obtained by abolishing the whole group of ailments classed together as "the seven principal zymotic diseases." As regards the three cliseases to combat which the expensive machinery of isolation hospitals chiefly exists-viz., typhoid fever, scarlet fever, and diphtheria-if they could be entirely exterminated the average increase in length of life of those at birth wonld only be increased by about a year, and those at age 15 would only have abont the fourth part of a year to add to their life expectation. Table VI. brings out prominently the fact that the group of tuberculons cliseases other than phthisis exert their maximum efforts at the earlier ages of life, these being more marked during the first five years, and after 15 years becoming comparatively insignificant. There is another

TABLE VII-Shlowing how the Inereased Expectation of Liff at Birth represented, in Table I. as produced by Elzminating Phthisis, would be Distributed. over the Foriods of Life indicated, and also a comparison with a sinular Distribution of the Expectation of Life at Birth calculated in Table $I \mathrm{~F}$.

\begin{tabular}{|c|c|c|c|c|c|c|c|c|}
\hline \multirow[b]{2}{*}{$\begin{array}{l}\text { Life } \\
\text { period. }\end{array}$} & \multirow[b]{2}{*}{$\begin{array}{l}\text { Age- } \\
\text { limits of } \\
\text { period. }\end{array}$} & \multirow[b]{2}{*}{ 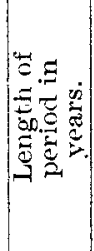 } & \multicolumn{3}{|c|}{ Males. } & \multicolumn{3}{|c|}{ Females. } \\
\hline & & & 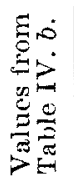 & 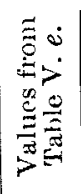 & 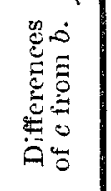 & 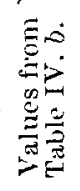 & 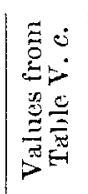 & 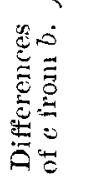 \\
\hline Infancy. & $0-5$ & 5 & $4 \cdot 02$ & $4 \cdot 02$ & \pm 0.00 & $4 \cdot 16$ & $4 \cdot 17$ & \pm 0.01 \\
\hline School-age. & $5-15$ & 10 & $7 \cdot 34$ & $7 \cdot 37$ & +0.03 & $7 \cdot 65$ & $7 \cdot 69$ & +0.04 \\
\hline $\begin{array}{l}\text { Working- } \\
\text { period of } \\
\text { lite. }\end{array}$ & $\left\{\begin{array}{l}15-25 \\
25-35 \\
35-45 \\
45-55 \\
55-65\end{array}\right\}$ & 50 & $\begin{array}{l}7 \cdot 03 \\
6 \cdot 61 \\
5 \cdot 97 \\
5 \cdot 10 \\
3 \cdot 91\end{array}$ & $\begin{array}{l}7 \cdot 14 \\
6 \cdot 86 \\
6 \cdot 41 \\
5 \cdot 67 \\
4 \cdot 49\end{array}$ & $\begin{array}{l}+0.11 \\
+0.25 \\
+0.44 \\
+0.57 \\
+0.58\end{array}$ & $\begin{array}{l}7 \cdot 33 \\
6 \cdot 89 \\
6 \cdot 30 \\
5 \cdot 54 \\
4 \cdot 48\end{array}$ & $\begin{array}{l}7 \cdot 46 \\
7 \cdot 19 \\
6 \cdot 75 \\
6 \cdot c 9 \\
5 \cdot c 0\end{array}$ & $\begin{array}{l}+0.13 \\
+0.20 \\
+0.45 \\
+0.55 \\
+0.52\end{array}$ \\
\hline $\begin{array}{l}\text { Totals for } \\
\text { of life ... }\end{array}$ & $\begin{array}{cc}\text { working } & p \\
\ldots & \ldots\end{array}$ & $\left.\begin{array}{ll}\text { eeriod } \\
\cdots & \ldots\end{array}\right\}$ & $26 \cdot 62$ & $30 \cdot 57$ & +1.95 & $30 \cdot 54$ & $32 \cdot 49$ & +1.95 \\
\hline Decline & $\begin{array}{l}65 \text { and } \\
\text { upwards. }\end{array}$ & - & $3 \cdot 34$ & 3.94 & +0.60 & 4.72 & $4 \cdot \varepsilon 9$ & +0.57 \\
\hline Total & All ages. & - & $43 \cdot 32$ & $45 \cdot 90$ & $+2 \cdot 58$ & $46 \cdot 67$ & $49 \cdot 24$ & +2.57 \\
\hline
\end{tabular}

TabLE VIII.-Shoning the Results of Tables IF., T., and VI., Re-worked out so as to give the Menn Expectation of Life possessed by the Individuals at all ages from $x$ to $x+n$ comprised within the respective Alje-groups $x$ to $x+n$ indicated.

\begin{tabular}{|c|c|c|c|c|c|c|}
\hline \multirow{2}{*}{$\begin{array}{c}\text { Age } \\
\text { groups } \\
x \text { to } x+n\end{array}$} & \multicolumn{3}{|c|}{ Males. } & \multicolumn{3}{|c|}{ Females. } \\
\hline & $b$. & $c$ & $d$. & $b$. & $c$. & d. \\
\hline $0-5$ & $51 \cdot 76$ & $+2 \cdot 680$ & $+3 \cdot 390$ & $54 \cdot 07$ & $+2 \cdot 380$ & +3.07 \\
\hline $5-10$ & $50 \cdot 58$ & $+3 \cdot 280$ & $+3 \cdot 6 \mathrm{CO}$ & $52 \cdot 56$ & $+3 \cdot 115$ & $+3 \cdot 4$ \\
\hline $10-15$ & $46 \cdot 49$ & +3.275 & +3.490 & 48.53 & +3.045 & +3.2 \\
\hline $15-25$ & $40 \cdot 33$ & +2.920 & $+3 \cdot 085$ & $42 \cdot 46$ & 585 & $+2 \cdot 7$ \\
\hline $25-35$ & $32 \cdot 61$ & $+2 \cdot 16$ & $+2 \cdot 270$ & $34 \cdot 82$ & +1 & $+1 \cdot 8$ \\
\hline $35-45$ & $25 \cdot 48$ & $+1 \cdot 355$ & $+1 \cdot 400$ & $27 \cdot 65$ & +0 & +0.98 \\
\hline $45-55$ & $18 \cdot 93$ & +0.685 & +0.705 & $20 \cdot 63$ & +0.430 & +0.450 \\
\hline $55-65$ & $13 \cdot c 6$ & +0.265 & +0.270 & $14 \cdot 24$ & +0.165 & +0.175 \\
\hline $65-$ & $8 \cdot 34$ & +0.070 & +0.070 & $9 \cdot c 6$ & +0.045 & +0.050 \\
\hline & $4 \cdot 94$ & +0.015 & +0.015 & $5 \cdot 41$ & +0.005 & +0.005 \\
\hline $85-95$ & $2 \cdot 78$ & +0.005 & +0.005 & $3 \cdot 11$ & \pm 0.000 & \pm 0.000 \\
\hline $95-$ & $1 \cdot 62$ & \pm 0.000 & \pm 0.000 & $1 \cdot 87$ & $\pm 0 \cdot 000$ & \pm 0.000 \\
\hline
\end{tabular}

The values teduced from Table IV. are hearled by $(b)$; the differences produced by eliminating phthisis are headed by $(c)$; and the rifferences produced by eliminating phthisis and all other tuberculous idiseases by $(l)$. aspect, however, under which the increased length of life bronght about by doing away with phthisis may be considered. It has been seen from 'lable $V$. that those at the very outset of life would on the average have two and a half years longer to live. Now it is of importance to ascertain, if

TABLE IX.-Showing, expressed in Years, the Total Life Capital in England and Wales at the Middle of the Year 1891, and to what extent this life Capital nould hav been Inoreased by Elininating (1) Ihthisis and (D) all other Tuberculous Disease as Causes of Mortality.

\begin{tabular}{|c|c|c|c|}
\hline Age groups. & \multicolumn{3}{|c|}{ Males. } \\
\hline & (b) & (c) & (d) \\
\hline $0-5$ & $91,741,447$ & $4,750,137$ & $1,258,431$ \\
\hline $5-10$ & $85,887,276$ & $5,569,598$ & 543,375 \\
\hline $10-15$ & $75, C 95,517$ & $5,290,124$ & 347,291 \\
\hline $15-25$ & $169,697,880$ & $7,942,420$ & 448,801 \\
\hline $25-35$ & $68,310,6 \varepsilon 9$ & $4,535,193$ & 219,952 \\
\hline $25-45$ & $41,163,557$ & $2,189,035$ & 72,699 \\
\hline $45-55$ & $22,622,863$ & 818,630 & 23,902 \\
\hline $55-65$ & $10,085,599$ & $2 C 4,617$ & 3,861 \\
\hline $65-75$ & $3,720,674$ & 31,220 & 0 \\
\hline $75-85$ & $7 £ 0,6 \subset 8$ & 2,188 & 0 \\
\hline $85-95$ & 44,116 & 79 & 0 \\
\hline 95- & 642 & 0 & 0 \\
\hline $\begin{array}{ccc}\text { Total } & \text { at } & \text { all } \\
\text { ages } & \ldots & \ldots\end{array}$ & $5 c 9,090,868$ & $z 1,333,250$ & $2,918,312$ \\
\hline Age groups. & \multicolumn{3}{|c|}{ Females: } \\
\hline & (b) & (c) & $(d)$ \\
\hline $0-5$ & $96.8 \approx 1.667$ & $4,262,241$ & $1,236, e 91$ \\
\hline $5--10$ & 89.694 .020 & $5,315,770$ & 597,277 \\
\hline $10-15$ & $78,480,8 \check{2} 0$ & $.4 .924,256$ & 328,119 \\
\hline $15-25$ & $122,824,802$ & $7,477,675$ & 433,908 \\
\hline $25-25$ & $79,913,154$ & 3.993 .263 & 183,603 \\
\hline $75-45$ & $47,626,288$ & $1,6 \geq 6,246$ & 77,511 \\
\hline $45-55$ & $26,998,237$ & 562,736 & 86,174 \\
\hline $55-65$ & $12,664,018$ & 146,729 & 4,447 \\
\hline $65-75$ & $4,951,028$ & 24,591 & 0 \\
\hline $75-85$ & $1, C 49,957$ & 970 & 0 \\
\hline $85-95$ & 82,788 & 0 & 0 \\
\hline $95-$ & 1,793 & 0 & 0 \\
\hline $\left.\begin{array}{rrr}\text { Total } & \text { at } & \text { all } \\
\text { ages } & \ldots & \ldots .\end{array}\right\}$ & $561,118,572$ & $28,344,687$ & $2,946,7 \geq 0$ \\
\hline
\end{tabular}

Sums of males and females- $-(b) 1.070,209,440:(c) 59,677,937$ : (d) $5,965,042$.

Average life capital for each individual Proportion per cent of life living.

\begin{tabular}{|c|c|c|c|c|c|c|}
\hline & \\
\hline- & - & $\begin{array}{l}\text { Increase } \\
\text { by elimi- } \\
\text { nating } \\
\text { phthisis. }\end{array}$ & $\begin{array}{l}\text { Further } \\
\text { increase by } \\
\text { eliminating } \\
\text { all other } \\
\text { tuberculous } \\
\text { diseases. }\end{array}$ & - & $\begin{array}{l}\text { With } \\
\text { phtihisis } \\
\text { elimi- } \\
\text { nated. }\end{array}$ & $\begin{array}{l}\text { With phthisis } \\
\text { and all other } \\
\text { tuberculous } \\
\text { cliseases } \\
\text { eliminated }\end{array}$ \\
\hline & (b) & (c) & $(d)$ & (b) & & \\
\hline Males... & $26 \cdot 13$ & $2 \cdot 22$ & 0.21 & $2 \cdot 768$ & $2 \cdot 608$ & $2 \cdot=94$ \\
\hline Females & $37 \cdot 43$ & $1 \cdot \varepsilon 9$ & 0.20 & $2 \cdot 672$ & 2.543 & $2 \cdot 530$ \\
\hline Persons & $36 \cdot 80$ & $2 \cdot 05$ & 0.21 & $2 \cdot 718$ & $2 \cdot 574$ & $2 \cdot 560$ \\
\hline
\end{tabular}

The calculations have been based (1) on the numbers given in the preceding Tahle VIII., and (2) on the numlers given in the census report, 1891 , Vol. IV Tahle 12 page 106 , as representing the estimated report, 1891 , ol. IV., Tahle 12 , page 106 , as representing the estimated population of England and Wales living at the midcle of the vear 1891 , classified into age ancl sex groups. Life capital deducen from Table IV. is headed by $(b)$, adrition by eliminating phithisis by $(c)$. and 
possible, how much of this added life would be lived during the part of life extending from age 15 to age 65 , which may be considered as the working period of life? 'This question is answered by Table VII., which shows that the working period of life would be lengthened on the average by very nearly two years. The matter may be illustrated in yet another way. 'The $E x$ values in Tables IV., V., and VI. apply to those at the exact age $x$, but if these values can be translated into those applying to age-groups, that is, into average values of expectation of life with relation to all the individuals at all ages from $x$ to $x+n$ comprised within the respective age-groups $x$ to $x+n$ (for example, from birth to age five, from age five to age 10 , \&c.), we shall then have a ready method of calculating what has been happily termed the "Life-capital" of a whole community. In Table VIII. such values have been worked out, and in Table IX. they have been used to show what was the total life-capital of the population of England and Wales as it existed at the middle of the year 1891, and to what extent the life-capital would have been increased (1) by abolishing phthisis and (2) by doing away with all other tuberculous diseases. A diagram also represents the results graphically to scale. However, the one striking and outstanding fact, which can-

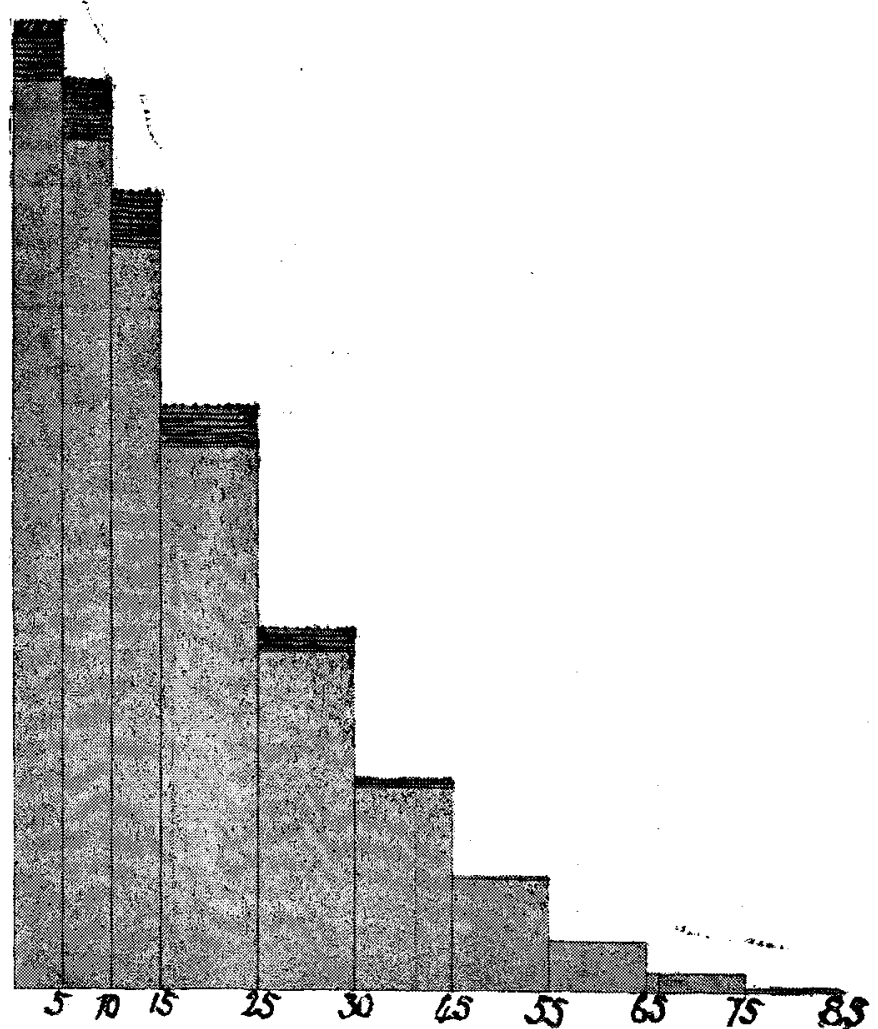

The areas of the parallelograms represent to scale the lifecapital of the respective age-groups numerixally stated in rapital of the respective age-groups numerically stated in from Table IV The tuansversely marked tops to the fron Talle colums inticate the increase of life-capital after excluding phthisis. The vertically marked tops to the column excluding all other tuberculous diseases.

not be emphasised more than by the mere statement of it, is that if phthisis had not existed as a cause of mortality in England and Wales every person living in the year 1891 would have had an average increase in life-capital of two years, and that the abolition of all other tuberculous diseases would only have increased the average life-capital by the fifth part of a year.

The question may now be asked, Are there any practical conclusions and deductions to be drawn from the statistical points which it has been sought to establish and to represent? Now years of human life are capable of being translated into terms of pounds, shillings, and pence, and it is evident that the ravages of phthisis must entail a very serious financial loss to the community. About 10 years ago, after reading a paper upon Life-table Construction before the Royal Statistical Society, I was met by a criticism, goodhumourediy, but at the same time pointedly, made, by a member of the actuarial profession present, that it would be better for a medical man to stick to his stethoscope and not to meddle with matters which properly belong to actuaries. My reply was to the effect that, whatever might be the case with medical men as practitioners, it was certainly open to a medical officer of health to utilise such little mathematical knowledge as he might possess in demonstrating the relations between lives and deaths. Shonld he, as only too probably he may, come short of the mathematical skill of the actuary he may gratefully accept such correction as the latter may be able to give. But when it comes to translating years of life into pecuniary valne the writer gladly concedes that this is the special work of the actuary and one for the dealing with which the community owes to him a debt of gratitude. Therefore $I$ can make no attempt to measure the financial loss due to phthisis or the possible gain by abolishing or considerably mitigating the effect of this disease. I would simply desire to represent to those concerned with the management of the industrial and other: life assurance societies that it might be not merely an act of benevolence and charity, but one of self-interest and profit to subscribe something towards the establishment and maintenance of sanatoria for the treatment of phthisis, so as tor aid in the restoration to health and the prolongation of life of those who are stricken with this disease and at the same. time to be limiting the diffusion of the infective germs to others. This course would not be without precedent for sich exists and is already given in Germany. It is only the adoption of a similar principle to that long ago acted upon in their own self-interest by companies insuring against loss by fireviz., either to maintain fire brigades of their own or to subscribe largely to those established by municipal enterprise.

\section{ON THE PHYSIOLOGICAL CURE OF THE: MORPHIA HABIT.}

By W. OSCAR JENNINGS, M.D. PARIS, M.R.C.S. EXG.

Is 1890 I published a little book on the cure of the morphia habit, giving an account of different means of treatment, based upon my researches concerning the craving that had enabled me to wean a considerable number of labitues from their addiction, with a minimum of distrens and suffering. It may seem an invidious thing to say, but I have no hesitation in declaring that before this there existed no treatment of the morphia craving founded upon therapentic indications. There was, in fact, no treatment of the craving at all, which is tantamount to saying that there was no systematic treatment of the morohia habit..' The so-called "methods" described by contemporary" writers consisted of suppressing the morphia suddenly slowly, or semi-brusquely, and those who could be persuader to give up their liberty, when they did not die suddenly or commit suicide, were sometimes cured temporarily after indescribable sufferings, ${ }^{2}$ but the same ignorance, or rather indifference, concerning the means of alleviating the craving, extended to the means of preventing the discomforts that are liable to occur to those who are left to their own devices after the suppression, and in nine cases out of ten the temporary suppression was followed by a speedy relapse.

I would say at once-for 1 have long ceasel to make any secret of the matter-that my first observations were made in my own case. I endeavoured to analyse and to dissociate the different factors of the miserable wretchedness known as the morphia craving, and I was able to satisfy myself that they were always intensified by a certain number of errors and imprudences that the morphine

1 I except that of Dr. Mattison of Brooklyn, who treats his patients by bromides, codeine, and cannalis indica.

2 A physician, quoted by Dr. Mattison, expresses himself as follows "Let him (the patient) quit it short, absolute, and entirely. If be have the will power, trust him; if he cheats, lock him up; put a Hercules over him as a nurse." As it is absolutely certain that no one whose addiction is of sufficient standing to warrant the expression "morphia habitue" could leave it off sudkenly by an effort of the will the Herculean nurse would become a necessity. Here is a picture of the treatment by the same authority. "All substitutes are simply a prolongation of the agony he must go through. ..... The patient who quits morphia, after a long-established halit, suffers from insomnia, cliarrhcea, nausea, vomiting, achings all over, and debility to such a degree that it is a marvel how he lives. ..... All this suffering will last from five to ten days. No medicine will do any gool, the stomach rejects everything, even a mouthful of cold water. It last, after several centuries of torture, little by little, and without. medicine or substitutes, nature accomplishes the cure. This terrible treatment. I am sure, is not only the best, but the only safe one to cure, and secure the patient from relapse." 